$\xi=\mathrm{r}$

\title{
Influence of thyroid hormones on nervous system development - brief review
}

\author{
Rafael Cisne $^{1 *}$, Rayssa Justo ${ }^{1}$, Edimilson Migowski $^{2}$ \\ ${ }^{1}$ Dept. of Morphology, Biomedical Center, Fluminense Federal University, Niterói, RJ, Brazil \\ ${ }^{2}$ Child Care and Pediatrics Institute Matagão Gesteira, Federal University of Rio de Janeiro - Brazil \\ *Corresponding author E-mail: rafael.cisne@gmail.com
}

\begin{abstract}
The thyroid gland secretes important hormones for the overall development of organism, which include some related to tissue growth, as well as hormones that stimulate the $\mathrm{O} 2$ uptake in the cells and help the regulation of lipid and carbohydrate metabolism. Therefore influence the body mass and activity level thereof, including the activities of nervous system. The thyroid gland is not essential for life, however their absence or hypofunction during fetal and neonatal life result in severe mental, physical and mental slowness, poor resistance to cold, as well as dwarfism. The hyperfunction of this gland leads to weight loss, nervousness, tachycardia, tremor and production of excess heat.
\end{abstract}

Keywords: Brain Development; Potassium Iodide; Supplements; Thyroid Hormones.

\section{Morphological considerations}

This glandular tissue derives embryologically from the stomodeum pharyngeal pouch and migrate from the thyroglossal duct to the neck, where is lodged. It has two morphological horns joined by an inferior isthmus, being suspended by a fascia against the first tracheal rings [1]

This tissue is part of the endocrine system, which comprises a series of glands that secrete substances known as hormones into the bloodstream. Among these secreted substances, there are certain hormones that help increasing the consumption of oxygen by the cells, and the metabolism of lipids and carbohydrates [2].

This gland has a large amount of follicles filled with substance colloid therein, being these cells responsible for synthesize and secrete a protein called thyroglobulin in these follicles [3]. Each thyroglobulin molecule contains the amino acid tyrosine in its composition, which is the basis for construction of thyroid hormones [4].

\section{Formation and secretion of thyroid hor- mones}

The synthesis of thyroid hormones is directly dependent on iodine and involves three basic steps [5]. First, iodine is absorbed on diet by digestory tract e transported by proteins of basal membrane from follicular cells into the cytoplasm keeping the intracellular iodine concentration always higher than in the extracellular fluid [6].

Once iodine uptake ion occurs, the $\mathrm{I}^{-}$captured by the follicular cell migrates to the apical surface, where it is oxidized and converted to its active form $\left(\mathrm{I}^{+}\right)$by the enzyme thyroid peroxidase $[7,8]$. The thyroid peroxidase enzyme is responsible for catalyzing the incorporation of $\mathrm{I}^{+}$to tyrosine residues and the binding of iodotyrosine molecules (already incorporated) in thyroglobulin (phenomenon known as organification) [9]. The now iodinated tyrosine molecules are grouped forming the molecules of thyroid hormones [5, 6] One diiodotyrosine added to one monoiodotyrosine results in 3,5,3 triiodothyronine (T3); whilst two diiodotyrosine will form thyroxine (T4) [9]. The hormone triiodothyronine (T3) is less abundant, but it has a much higher biological activity than thyroxine (T4) [10], [11].

Thus, it is clear that iodine is an essential raw material for the synthesis of thyroid hormones. It is taken in food and absorbed into the circulation. The minimum amount of daily consumption is $150 \mu \mathrm{g} /$ day in adults [12]. However, according to World Health Organization (WHO) and International Council for the Control of Iodine Deficiency Disorders (ICCIDD) guidelines, median urinary iodine values for pregnant women between 150 and $249 \mu \mathrm{g} / \mathrm{L}$ are consistent with optimal iodine intake [12].

\section{Metabolism of thyroid hormones}

After its formation, a part of thyroid hormones is stored and a part is released (by the action of TSH or thyroid stimulating hormone). It is also known that only around $20 \%$ of the daily production of T3 is released directly into the circulation by the thyroid gland, since most of the conversion of $\mathrm{T} 4$ to $\mathrm{T} 3$ occurs in peripheral tissues [10] [11]. This process in which the precursor of (T4) is converted to the active form of the hormone (T3) is known as central and peripheral deiodination, and it is accepted that this process is one of the control pathways of the bioavailability of this hormone [13] [14].

$\mathrm{T} 3$ and T4 are deiodinated in the liver, kidneys and other organs [15]. These deiodination reactions works not only to catabolize the hormones, but also to provide local source of T3 [13]. About onethird (1/3) of circulating T4 is converted to T3, 13\% of T3 is released into the thyroid and $87 \%$ formed by deiodination [13] [15]. The deiodination is performed primarily by two enzymes: the deiodinases 1 and 2 (DIO1 and DIO2) [13] [16]. The DIO1 is 
present in liver, kidney, thyroid, and hypophysis DIO2 is in the hypophysis, brain (is in astrocytes and generates a T3 reservation for neurons; Figure 1) and brown adipose tissue [15] [13]

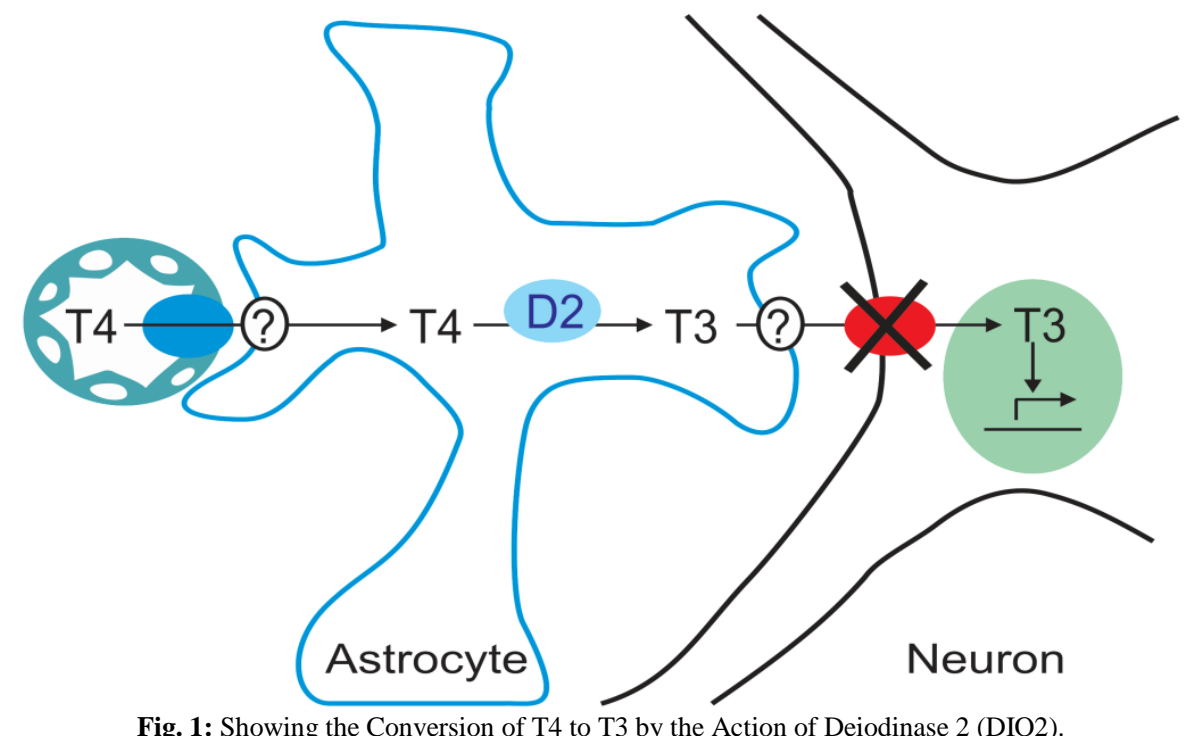

\section{Features and functions of T3 and T4 hor- mones}

Thyroid hormones are hydrophobic molecules, liposoluble and therefore cross the cell membrane of most cells where they will perform their biological roles. Among its functions include the elevation of mitochondrial ATP synthesis [17], as well as having effects on body weight and fat metabolism [2]. Other non-genomic functions of thyroid hormones include modulation of intracellular levels of $\mathrm{Na}^{+}, \mathrm{Ca}^{2+}, \mathrm{K}^{+}$, glucose transport, the activation of PKC (protein kinase C), PKA (protein kinase A), ERK / MAPK (kinase regulated by extracellular signals and mitogen-activated protein kinase, respectively) and the regulation of phospholipid metabolism by the activation of phospholipase $\mathrm{C}$ and phospholipase $\mathrm{D}$ [18]. Therefore, its functions are associated with increased consumption of oxygen in the cells, growth and development of mammals, lipidic metabolism, enhance absorption of carbohydrates and regulate thermogenesis [2].

\section{Mechanisms of action}

The receptors for thyroid hormones vary in quantity and expression in different types of tissues [19].

In general, thyroid hormones bind to intracellular receptors, which will bind to the DNA sequences called responsive elements to thyroid hormones forming preferentially heterodimers [20]. The mRNA of receptors for thyroid hormone (TR) was detected during the development by the eleventh and fifteenth embryonic day (E11-E15) in the CNS of rats and its protein was detected in different brain regions of rats in the fourteenth embryonic day - E14 [21].

The family receptors for thyroid hormone (TR) consists of two isoforms: $\alpha$ receptors for thyroid hormones (TR $\alpha)$ and $\beta$ receptors for thyroid hormones (TR $\beta)$ [22]. The TR $\alpha$ receptors are still divided into TR $\alpha 1, T R \alpha 2$ and TR $\alpha 3$. The three isoforms differ in their carboxyterminal portion, only TR $\alpha 1$ bounds to T3 [23]. Two other variants of TR $\alpha$, TR $\Delta \alpha 1$ and TR $\Delta \alpha 2$ that have been identified appear not to bind to T3 nor DNA, proving to be inhibitors of TR [24].

The second group of receptors, TR $\beta$, include the TR $\beta 1 \operatorname{TR} \beta 2$, TR $\beta 3$ TR $\Delta \beta 3$ variants [22]. These three proteins demonstrated to play different roles among themselves. In fact, we can consider receptors for thyroid hormones in the literal sense of the word, only the isoforms of TR $\alpha 1, T R \beta 1$ and TR $\beta 2$, for binding to T3 and activating or inhibiting gene transcription [25].
Studies using TR $\alpha 1$ and TR $\beta$ receptors with mutations that removed their ability to connect to T3 suggest an important role of non-activated TRs, explaining, at least in part, this discrepancy phenomena [26]. These facts also support the hypothesis of the importance of non-genomic actions of thyroid hormones (such as actin polymerization, neurite outgrowth and synaptic efficacy).

Thyroid hormones play also a key role during the critical period, relating to axonal outgrowth, synapse formation, myelination, proliferation and neuronal migration [25].

\section{T3 and T4 effects in nervous system devel- opment}

The appearance of the thyroid in rats occurs approximately at the ninth embryonic day (E9) [27]. In this step, the gland already concentrates thyroglobulin and is able to perform the uptake of iodine. Basically, hormone embryo source is maternal. The detection of the hormone in mouse embryo happens already in the ninth embryonic day (E9), with different levels of T3 and T4, being T3 the most abundant [27]. Experimental reports have demonstrated that the mouse trophoblasts had a concentration of $21 \%$ of the maternal concentration of $\mathrm{T} 4$ and $54 \%$ of $\mathrm{T} 3$ [28], as well as experiments demonstrated that even small deficiencies of maternal iodine are able to reduce the T4 levels of the fetus [29], showing that normal maternal serum levels of $\mathrm{T} 4$ are critical to maintaining adequate levels of this hormone in the embryo a suitable local conversion to T3. The total levels of T3 and T4 increased significantly from E18 to birth by the maturation of the thyroid gland. After birth, the plasma levels of $\mathrm{T} 4$ rises sharply to a peak in the seventeenth postnatal day (DPN17) [30], followed by an elevation in parallel, T3 levels which will reach its peak in DPN28. The total T3 levels that are standard in adult rats are achieved in DPN40 [27].

Thyroid hormones are essential for brain development [31]. The early development of neural tube, by the eighth embryonic day (E8), coincides with the beginning of development of thyroid and, somehow, with the emergence of receptors for thyroid hormones [27]. During the same period, neurogenesis in the central nervous system starts (from E10) [31].

Various phenomena of development (and adulthood) are influenced by thyroid hormones, such as axonal and neuritic growth, synaptogenesis, neuronal survival and migration, myelination and synaptic efficacy [32]. In cerebellar ontogenesis, for example, experiments have shown that thyroid hormones act by mediating epidermal growth factor (EGF), providing an increase of neurite numbers in astrocytes [33]. The regulation of neurotransmitter release in the hippocampus was also influenced by the presence of 
thyroid hormones; electrophysiological studies of short-term synaptic plasticity showed that facilitation of paired pulse patterns were found to be extremely modified in animals with hypothyroidism, this condition being reversible with the administration of thyroid hormones [34].

Investigations on cell proliferation in the sub-ventricular zone (SVZ) of the hippocampus also demonstrated that T3 and its receptor alpha (TR $\alpha$ ) play an important role in neurogenesis in this region [35]. Effects on extracellular matrix synthesis were also observed in cerebellum, since the absence of thyroid hormones delay laminin expression [36] [37], and their levels were 35\% lower than control animals (Farwell et al., 1995).

In the cerebellum, several anatomical alterations induced by perinatal hypothyroidism have been documented, as follow: reduction of growth and branching of dendritic arborization of Purkinje cells [39] [40] [41] [42]; decrease of synaptogenesis between Purkinje cells and granule cell axons [42] [43]; delayed proliferation and migration of granule cells [44]; delayed myelination [45]; and changes in synaptic connection among cerebellar neurons and afferent neuronal fibers [46] [47] (Figure 2).
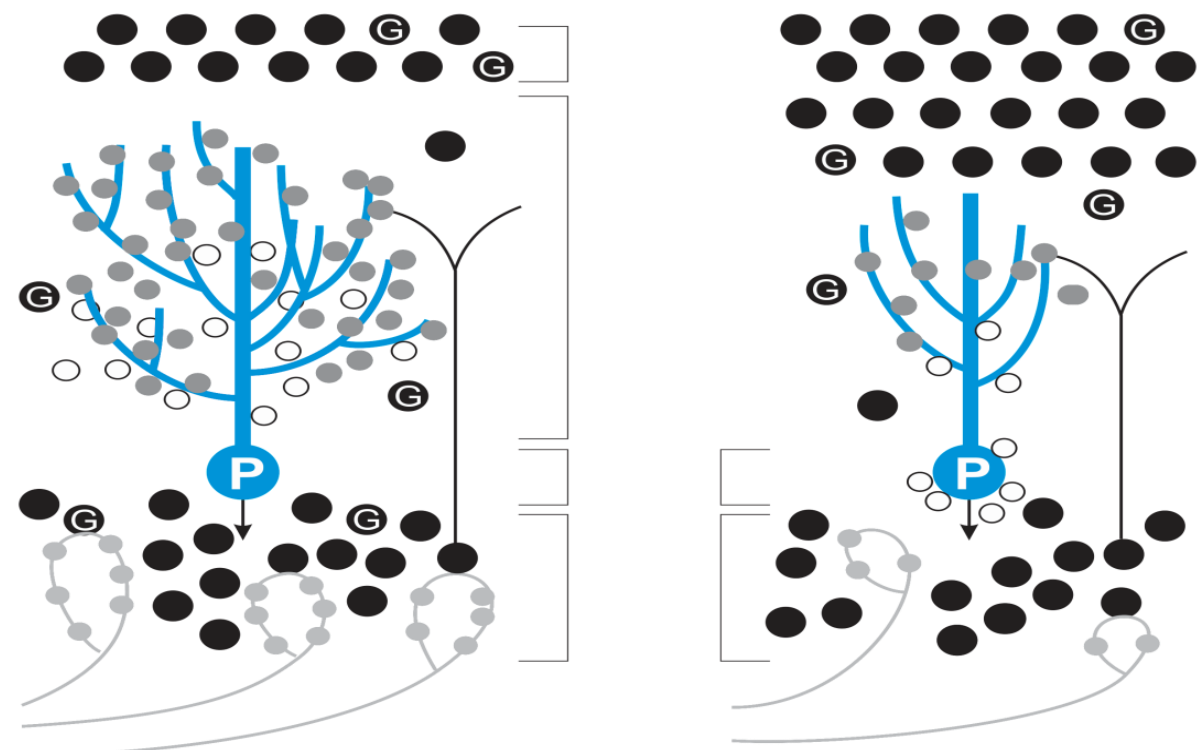

Fig. 2: Schematic Images Show the Layers of the Cerebellar Cortex Cells; on the Left, the Layers of A Euthyroid Individual (Normal Levels of Thyroid Hormones) Cells with Extensive Branching (Especially Purkinje Cells, "P" - Blue) Forming Extensive Number of Synapses; and on the Right, the Cell Layout of A Cerebellar Cortex of an Individual with Reduced Levels of Thyroid Hormones, Showing Low Branching Cells (Including Purkinje Cells Blue) and Reduced Number of Synapses.

\section{Effects of inadequate dietary intake of io- dine to the nervous system}

Congenital hypothyroidism is the most common and treatable cause of mental retardation and its prevalence in this context is about $1 / 3000$ births [48]. Congenital hypothyroidism is a major cause of mental retardation in humans, and effects related to hypothyroidism (deficiency of thyroid hormones) congenital vary with the intensity of disability [49]. The cretinism is the most severe picture related to congenital hypothyroidism and includes symptoms such as spasticity, severe mental retardation and deafness [50]. Poor motor coordination effects, ataxias, spastic diplegia, muscular hypotonia, strabismus and learning disorders also are related to congenital hypothyroidism [48]. Frameworks of depression and memory disorders are also present in adults [51].

Despite knowing these aspects, little is known about the cellular, molecular mechanisms and pathways by which thyroid hormones act in regulating the nervous system. There are still several issues related to the phenomena involved in these processes. The accurate determination of the cause of the disturbances found so far, are derived directly from the maternal hormonal deficit [52], secondary to metabolic disorders of the fetus or both.

\section{Conclusion}

Therefore, it is clear that the normal development of the nervous system requires adequate amounts of T4 throughout the development. Initially it is provided by the mother and then the maternal and fetal thyroid. We can conclude that sufficient $\mathrm{T} 4$ production by maternal and fetal thyroid requires increase in the dietary intake of iodine [19] [50], and supplements containing potassium iodide (KI) is strongly recommended.

\section{References}

[1] Gray, H: Gray Anatomia. 29 ${ }^{\mathrm{a}}$ Ed. Rio de Janeiro: Guanabara Koogan S.A, Rio de Janeiro, Brazil, 1988. (1097-1099).

[2] Lomenick, J. P., M. El-Sayyid \& W. J. Smith. "Effect of levothyroxine treatment on weight and body mass index in children with acquired hypothyroidism." J Pediatr 152(1), 2008, 96-100. http://dx.doi.org/10.1016/j.jpeds.2007.06.006.

[3] Kirsten, D., "The thyroid gland: physiology and pathophysiology." Neonatal Netw 19(8), 2000, 11-26. http://dx.doi.org/10.1891/07300832.19.8.11.

[4] Lin, J. D., "Thyroglobulin and human thyroid cancer." Clin Chim Acta 388(1-2), 2008, 15-21. http://dx.doi.org/10.1016/j.cca.2007.11.002.

[5] Li, H. S. \& G. Carayanniotis. "Induction of goitrous hypothyroidism by dietary iodide in SJL mice." Endocrinology 148(6), 2007, 2747-52. http://dx.doi.org/10.1210/en.2007-0082.

[6] Gluzman, B. E. \& H. Niepomniszcze. "Kinetics of the iodide trapping mechanism in normal and pathological human thyroid slices." Acta Endocrinol (Copenh) 103(1), 1983, 34- 9. http://dx.doi.org/10.1530/acta.0.1030034.

[7] Cooper, D. S., "Antithyroid drugs." N Engl J Med 311(21), 1984 1353-62. http://dx.doi.org/10.1056/NEJM198411223112106.

[8] Darbra, S., F. Balada, M. A. Marti-Carbonell \& A. Garau, "Perinatal hypothyroidism effects on step-through passive avoidance task in rats." Physiol Behav 82(2-3), 2004, 497-501 http://dx.doi.org/10.1016/j.physbeh.2004.04.057.

[9] Bernal, J., A. Guadano-Ferraz \& B. Morte, "Perspectives in the study of thyroid hormone action on brain development and function." $\quad$ Thyroid 13(11), 2003, 1005-12. http://dx.doi.org/10.1089/105072503770867174.

[10] Leonard, J. et al., Cerebral cortex responds rapidly to thyroid hormones. Science 214, 1981, 571-573 http://dx.doi.org/10.1126/science.7291997.

[11] Cassio, A., E. Cacciari, A. Cicognani, G. Damiani, G. Missiroli, E Corbelli, A. Balsamo, M. Bal \& S. Gualandi, "Treatment for congenital hypothyroidism: thyroxine alone or thyroxine plus triiodo- 
thyronine?" Pediatrics 111(5 Pt 1$), \quad 2003, \quad 1055-60$ http://dx.doi.org/10.1542/peds.111.5.1055.

[12] Stagnaro-Green A, Sullivan S, Pearce EN., Iodine supplementation during pregnancy and lactation. Jama 308, 2012, 2463-2464. http://dx.doi.org/10.1001/jama.2012.45423.

[13] Guadaño-Ferraz,A.etal., Thetype2 iodothyronine deiodinase is expressed pri- marily in glial cells in the neonatal rat brain. Proc. Natl. Acad. Sci. U. S. A. 94, 1997, 10391-10396 http://dx.doi.org/10.1073/pnas.94.19.10391.

[14] Wu, S. Y., W. L. Green, W. S. Huang, M. T. Hays \& I. J. Chopra, "Alternate pathways of thyroid hormone metabolism." Thyroid 15(8), 2005, 943-58. http://dx.doi.org/10.1089/thy.2005.15.943.

[15] Calvo, R. et al., Congenital hypothyroidism, as studied in rats. J. Clin. Invest. 86, 1990, 889-899 http://dx.doi.org/10.1172/JCI114790.

[16] Kohrle, J., "Thyroid hormone transporters in health and disease: advances in thyroid hormone deiodination." Best Pract Res Clin Endocrinol Metab 21(2), 2007, 173-91. http://dx.doi.org/10.1016/j.beem.2007.04.001.

[17] Verhoeven, A. J., P. Kamer, A. K. Groen \& J. M. Tager, "Effects of thyroid hormone on mitochondrial oxidative phosphorylation." Biochem J 226(1), 1985, 183-92. http://dx.doi.org/10.1042/bj2260183.

[18] Kavok, N. S., O. A. Krasilnikova \& N. A. Babenko, "Thyroxine signal transduction in liver cells involves phospholipase $\mathrm{C}$ and phospholipase D activation. Genomic independent action of thyroid hormone." BMC Cell Biol 2, 2001, 5 . http://dx.doi.org/10.1186/1471-2121-2-5.

[19] Escobar GM, Ares S, Berbel P, Obregon MJ, del Rey FE., The changing role of maternal thyroid hormone in fetal brain development. Semin Perinatol 32, 2008, 380-386 http://dx.doi.org/10.1053/j.semperi.2008.09.002.

[20] Dumitrescu, A. M. \& S. Refetoff, "Novel biological and clinical aspects of thyroid hormone metabolism." Endocr Dev 10, 2007, 127-39. http://dx.doi.org/10.1159/000106824.

[21] Bradley, D. J., H. C. Towle \& W. S. Young, 3rd. "Spatial and temporal expression of alpha- and beta-thyroid hormone receptor mRNAs, including the beta 2-subtype, in the developing mammalian nervous system." J Neurosci 12(6), 1992, 2288-302.

[22] Bernal, J., "Thyroid hormone receptors in brain development and function." Nat Clin Pract Endocrinol Metab 3(3), 2007, 249-59. http://dx.doi.org/10.1038/ncpendmet0424.

[23] Morte, B., M. A. Iniguez, P. I. Lorenzo \& J. Bernal, "Thyroid hormone-regulated expression of RC3/neurogranin in the immortalized hypothalamic cell line GT1-7." J Neurochem 69(3), 1997, 902-9. http://dx.doi.org/10.1046/j.1471-4159.1997.69030902.x.

[24] Fraichard, A., O. Chassande, M. Plateroti, J. P. Roux, J. Trouillas, C. Dehay, C. Legrand, K. Gauthier, M. Kedinger, L. Malaval, B. Rousset \& J. Samarut. "The T3R alpha gene encoding a thyroid hormone receptor is essential for post-natal development and thyroid hormone production." Embo J 16(14), 1997, 4412-20. http://dx.doi.org/10.1093/emboj/16.14.4412.

[25] Konig, S. \& V. Moura Neto, "Thyroid hormone actions on neura cells." Cell Mol Neurobiol 22(5-6), 2002, 517-44. http://dx.doi.org/10.1023/A:1021828218454.

[26] Gothe, S., Z. Wang, L. Ng, J. M. Kindblom, A. C. Barros, C. Ohlsson, B. Vennstrom \& D. Forrest, "Mice devoid of all known thyroid hormone receptors are viable but exhibit disorders of the pituitary-thyroid axis, growth, and bone maturation." Genes Dev 13(10), 1999, 1329-41. http://dx.doi.org/10.1101/gad.13.10.1329.

[27] Fisher, D. A. \& A. H. Klein, "Thyroid development and disorders of thyroid function in the newborn." N Engl J Med 304(12), 1981, 702-12. http://dx.doi.org/10.1056/NEJM198103193041205.

[28] Woods, R. J., A. K. Sinha \& R. P. Ekins, "Uptake and metabolism of thyroid hormones by the rat foetus in early pregnancy." Clin Sci (Lond) 67(3), 1984, 359-63. http://dx.doi.org/10.1042/cs0670359.

[29] Klein, R. Z., J. D. Sargent, P. R. Larsen, S. E. Waisbren, J. E. Haddow \& M. L. Mitchell, "Relation of severity of maternal hypothyroidism to cognitive development of offspring." J Med Screen 8(1), 2001, 18-20. http://dx.doi.org/10.1136/jms.8.1.18.

[30] Fisher, D. A., J. H. Dussault, J. Sack \& I. J. Chopra, "Ontogenesis of hypothalamic--pituitary--thyroid function and metabolism in man, sheep, and rat." Recent Prog Horm Res 33, 1976, 59-116.

[31] Solis, J. C. \& C. Valverde, "[Neonatal hypothyroidism. pathophysiogenic, molecular and clinical aspects]." Rev Invest Clin 58(4), 2006, 318-34

[32] Thompson, C. C. \& G. B. Potter, "Thyroid hormone action in neural development." Cereb Cortex 10(10), 2000, 939-45. http://dx.doi.org/10.1093/cercor/10.10.939.

[33] Martinez, R. \& F. C. Gomes, "Neuritogenesis induced by thyroid hormone-treated astrocytes is mediated by epidermal growth fac- tor/mitogen-activated protein kinase-phosphatidylinositol 3-kinase pathways and involves modulation of extracellular matrix proteins." J Biol Chem 277(51), 2002, 49311-8. http://dx.doi.org/10.1074/jbc.M209284200.

[34] Vara, H., B. Martinez, A. Santos \& A. Colino, "Thyroid hormone regulates neurotransmitter release in neonatal rat hippocampus." Neuroscience $\quad 110(1), \quad 2002$, http://dx.doi.org/10.1016/S0306-4522(01)00541-3.

[35] Lemkine G. F., A. R., G. Alfama, N. Turque, Z. Hassani, O. Alegria-Prévot, \& G. L. J. Samarut, and B. A. Demeneix, "Adult neural stem cell cycling in vivo requires thyroid hormone and its alpha receptor." The FASEB Journal: 17, 2005.

[36] Siegrist-Kaiser, C.A. et al., Thyroxine-dependent modulation of actin polym- erization in cultured astrocytes. J. Biol. Chem. 265, 1990, 5296-5302

[37] Farwell, A.P. and Dubord-Tomasetti, S.A., Thyroid hormone regulates the extracellular organization of laminin on astrocytes. Endo$\begin{array}{llll}\text { crinology } & 140, & 1999, & 5014-5021\end{array}$ http://dx.doi.org/10.1210/en.140.11.5014.

[38] Farwell, A. P., M. P. Tranter \& J. L. Leonard, "Thyroxinedependent regulation of integrin-laminin interactions in astrocytes." Endocrinology 136(9), 1995, 3909-15.

[39] Legrand, J., Variations, en fonction de l'âge, de la réponse du cervelet a l'action morphogénétique de la thyroïde chez le rat. Arch. Anat. Microsc. Morphol. Exp. 56, 1967, 291-308

[40] Legrand, J., Morphogenetic actions of thyroid hormones. Trends Neurosci. 2, 1979, 234-236 http://dx.doi.org/10.1016/01662236(79)90091-2.

[41] Koibuchi, N. and Chin, W.W., Mechanisms underlying neurological ab- normalities resulting from developmental hypothyroidism. Curr. Opin. Endocrinol. Diabet. 6, 1999, 26-32 http://dx.doi.org/10.1097/00060793-199902000-00005.

[42] Nicholson, J.L. and Altman, J., The effects of early hypo- and hyperthyroidism on the development of the rat cerebellar cortex. II Synaptogenesis in the molecular layer. Brain Res. 44, 1972, 25-36 http://dx.doi.org/10.1016/0006-8993(72)90363-0.

[43] Nicholson, J.L. and Altman, J., Synaptogenesis in the rat cerebellum: effects of early hypo- and hyperthyroidism. Science 176, 1972, 530-532 http://dx.doi.org/10.1126/science.176.4034.530.

[44] Nicholson, J.L. and Altman, J., The effects of early hypo- and hyperthyroidism on development of rat cerebellar cortex. I. Cell proliferation and differentiation. Brain Res. 44, 1972, 13-23 http://dx.doi.org/10.1016/0006-8993(72)90362-9.

[45] Legrand, J., Effects of thyroid hormone on brain development, with particular emphasis on glial cells and myelination. In Multidisciplinary Approach to Brain Development (Di Benedetta, C. et al., eds) Elsevier, 1980, 279-292.

[46] Hajós, F. et al., Effect of thyroid de- ficiency on the synaptic organization of the rat cerebellar cortex. Brain Res. 50, 1973, 387-401 http://dx.doi.org/10.1016/0006-8993(73)90740-3.

[47] Koibuchi N, Chin WW., Thyroid hormone action and brain development. Trends Endocrinol Metab 11, 2000, 123-128. http://dx.doi.org/10.1016/S1043-2760(00)00238-1.

[48] Buyukgebiz, A., "Congenital hypothyroidism clinical aspects and late consequences." Pediatr Endocrinol Rev 1 Suppl 2, 2003 185-90 discussion 190.

[49] Goodman, J. H. \& M. E. Gilbert, "Modest thyroid hormone insufficiency during development induces a cellular malformation in the corpus callosum: a model of cortical dysplasia." Endocrinology 148(6), 2007, 2593-7. http://dx.doi.org/10.1210/en.2006-1276.

[50] Morreale de Escobar, G., M. J. Obregon \& F. Escobar del Rey, "Fetal and maternal thyroid hormones." Horm Res 26(1-4), 1987, 1227. http://dx.doi.org/10.1159/000180681.

[51] Rivas, M. \& J. R. Naranjo, "Thyroid hormones, learning and memory." Genes Brain Behav 6 Suppl 1, 2007, 40-4. http://dx.doi.org/10.1111/j.1601-183X.2007.00321.x.

[52] Oppenheimer, J. H. \& H. L. Schwartz, "Molecular basis of thyroid hormone- dependent brain development." Endocr Rev 18(4), 1997, 462-75. http://dx.doi.org/10.1210/er.18.4.462. 